\title{
REVIEW
}

\section{Prospective Use of 1-Aminocyclopropane-1-Carboxylate Deaminase-Producing Bacteria for Plant Growth Promotion and Defense against Biotic and Abiotic Stresses in Peat-Soil-Agriculture}

\author{
EDI HUSEN ${ }^{1}$, ARIS TRI WAHYUDI ${ }^{1 *}$, ANTONIUS SUWANTO ${ }^{1}$ AND RASTI SARASWATI \\ ${ }^{1}$ Department of Biology, Institut Pertanian Bogor, Darmaga Kampus, Bogor 16680, Indonesia; \\ ${ }^{2}$ Indonesian Soil Research Institute, Jalan Ir. H. Juanda 98, Bogor 16123, Indonesia
}

\begin{abstract}
The 1-aminocyclopropane-1-carboxylate (ACC) deaminase (EC4.1.99.4) is an enzyme produced by some soil bacteria to degrade ACC (the immediate precursor of ethylene) to reduce ethylene biosynthesis in higher plants. Increased concentrations of ethylene in plant tissues, which are triggered by various biotic and abiotic stresses, inhibits plant growth and weakens the plant defense against the stressors. Various findings on the successful use of ACC deaminase producing bacteria for plant growth under unfavorable soil conditions are inspiring their use in tropical peat-soil-agriculture, which possesses bio-physical constraints. It has been proven that inoculation of plants with ACC deaminase producing bacteria decreased ethylene inhibition generated by unfavorable environmental conditions, such as nutrient shortage, flooding, drought, high salts, and the presence of heavy metals and organic pollutants. Understanding the mechanisms by which ACC deaminase-producing bacteria act to reduce plant stress and the fitness of bacterial traits with the properties and constraints of peat-soils becomes a key to utilize these bacteria in improving crop productivity. The bacteria may ameliorate plant stress as well as promote plant growth under seasonal bio-physical changes of peat-soils that are usually encountered in the field.
\end{abstract}

Key words: ACC deaminase, bacteria, plant growth promotion, biotic and abiotic stresses, peat-soil

Peat-soils are important in the world to support human welfare, both locally and globally. They cover about 400 million ha area in the world (Malmer et al. 1994; Rubec 1996), 40 million ha of which are found in tropical regions and half of which are located in Indonesia (Driessen and Subagjo 1977; Widjaya-Adhi et al. 1997). Despite their potential use for agriculture, especially those of shallow peat-soils (Widjaya-Adhi et al. 1997), bio-physical constraints of these soils limit their capacity to produce optimal yields. Besides high acidity ( $\mathrm{pH} 3.5$ to 5.0), most tropical peat-soils are deficient in macro- and micro-nutrients (Driessen and Subagjo 1977; van Breemen 1995; Widjaya-Adhi et al. 1997). Incomplete decomposition of organic matter during peat formation also results in the accumulation of various phytotoxins, which inhibit plant growth (Salampak et al. 2000; Hartatik and Suriadikarta 2003). Water-logged conditions coupled with bio-physical constraints of peat-soils are considered both conducive and suppressive to soil-borne pathogens (Hoitink and Boehm 1999; Hunter et al. 2006). Thus, plants growing in these harsh soil conditions may be confronted with various stresses, unless a promising technology to reduce plant stress is applied.

The 1-aminocyclopropane-1-carboxylate (ACC) deaminase (EC4.1.99.4) is an enzyme produced by some soil borne bacteria to hydrolyze ACC, the immediate precursor of ethylene in higher plants, as their source of nitrogen (Jacobson et al. 1994; Glick 1995). The benefits of ACC deaminase-producing bacteria to diverse aspects of plant growth have been reported in various environmental conditions. These bacteria can reduce plant stress by

*Corresponding author, Phone/Fax: +62-251-8622833, E-mail: atriw@ipb.ac.id controlling ethylene synthesis in plant tissues, which can be induced by various unfavorable environmental conditions including pathogens attack. Although this plant hormone ethylene has profound effects on plant growth and physiology, increased concentration of ethylene at an early stage of plant growth inhibits root development and weakens plant defense against various stressors (Glick 1995; Shah et al. 1997; Glick et al. 2007). A study by Wang et al. (2000), using ACC deaminase-producing Pseudomonas sp. and Enterobacter sp., demonstrated the effectiveness of these bacteria in enhancing growth and suppressing damping-off of cucumber root-rot diseases in tomato and potato. Subsequent studies revealed that these bacteria helped plants cope against various environmental constraints, such as heavy metals (Belimov et al. 2001), flooding (Grichko and Glick 2001), nutritional stress (Belimov et al. 2002), drought (Mayak et al. 2004), organic pollutants (Reed and Glick 2005) and high salts (Saravanakumar and Samiyappan 2007), which are present in most tropical peat-soils. Many more ACC deaminase-producing bacteria are still being studied to increase plant growth by using known strains or local isolates obtained from local soils. Our preliminary studies on some Pseudomonas sp. producing ACC deaminase isolated from the rhizosphere of soybean showed significantly increased soybean root-growth upon inoculation (Husen et al. 2008), so potentially this can be used as a plant helper in unfavorable soil conditions.

Based on the ability of ACC deaminase-producing bacteria to promote plant growth and provide defense against various environmental stresses, introducing these bacteria in unfavorable tropical peat-soil-agriculture may become an attractive solution to increase crop productivity. 


\section{Peat-Soils, Characteristics and Constraints}

Peat-soils are characterized by the accumulation of organic matter from dead and partially decaying plant materials under water-saturated conditions in wetland ecosystems. They are classified as histosols and mainly divided into fibric, hemic and sapric, based on the degree of organic material decomposition, i.e. partially, intermediately and highly decomposed materials, respectively (McKenzie 1974). The thickness of peat-soils varies from shallow $(50$ to $100 \mathrm{~cm})$ to very deep $(>300 \mathrm{~cm})$. Approximately 7.5 million ha of peat-soils in Sumatra and Kalimantan islands are suitable for agriculture (food and tree crops);

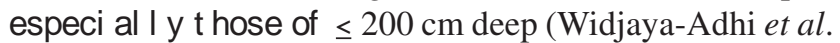
1997)

Peat-soils develop either from bogs which are rain-fed and nutrient-poor or fens which are fed by surface or ground water and more nutrients-rich (Malmer et al. 1994). Tropical peat-soils developed from ombrogenous bogs are found in shallow depressions in the natural basins between levees (banks) of rivers traversing the coastal plain (Driessen and Subagjo 1977). Since water, organic matter and its vegetation are all interconnected, the variations of peat-soil properties are mainly determined by these three components. Therefore, a change of any one of these components will fundamentally alter the nature of peat-soils (Rubec 1996); such that they are considered as fragile soil ecosystems.

Ample reports on the constraints of peat-soils for agriculture are well documented. The extreme conditions of tropical peat-soils which prevent normal plant growth include: (i) anaerobic conditions and the presence of toxic ions in the root zone, such as $\mathrm{Fe}^{2+}, \mathrm{Mn}^{2+}, \mathrm{S}^{2-}$ (Ponnamperuma 1972; Driessen and Subagjo 1977); (ii) water-logging or high water levels that deprive oxygen from perennial plants (van Breemen 1995); (iii) spongy soil structure that weakens rooting so trees easily fall down (Malmer et al. 1994); (iv) scarcity of nutrients as a result of peat accumulation (by which nutrients are fixed or chelated) and leaching by peat water (Driessen and Subagjo 1977; Widjaya-Adhi et al. 1997); (v) acidity (pH 3.5 to 5.0) caused by organic acids and cation exchange (van Breemen 1995; Widjaya-Adhi et al. 1997); and (vi) the presence of toxic organic substances, such as phenolic acids, produced during anaerobic decomposition of organic materials (Salampak et al. 2000). Moreover, peatsoils are conducive to the development of soil-bornepathogen diseases, such as Pythium sylvaticum-induced damping-off although some of them suppress disease (Hoitink and Boehm 1999; Hunter et al. 2006). These conditions may inhibit plant growth and prevent the proliferation of certain beneficial microbes, unless both plants and microbes develop several strategies to survive under these unfavorable or stress conditions.

Feng et al. (2002) reported that some root-nodule-forming bacteria developed thickened cell walls as a mechanism for long-term survival under nutrient-limited conditions of peatsoils. Involvement of certain bacteria to detoxify or transform phytotoxins generated during peat formation, which benefits both plants and microbes, has been reported (Huang and Kuhlman 1991; Blum et al. 1999). However, since peat-soils possess various complex biophysical constraints, various levels of plant stresses under these harsh soil conditions may not be difficult to understand. Most crop yields produced in peat-soils are less than those in mineral soils. The yields of food crops in peat-soils range from 2.7 to 4.1 ; 0.8 to 1.0 ; and 1.5 to 2.4 ton ha ${ }^{-1}$ for paddy field and corn; soybean and mung bean, respectively (Widjaya-Adhi et al. 1997). Therefore, reducing plant stress would potentially increase crop yields.

\section{ACC Deaminase and Plant-Growth-Promotion}

The ACC deaminase is a cytoplasmically localed enzyme (Jacobson et al. 1994) produced by soil microorganisms. It degrades cyclopropanoid amino ACC (the immediate precursor of the plant growth regulator ethylene) to form ammonia and $\alpha$-ketobutyrate. After the first finding of ACC deaminase from Pseudomonas sp. strain ACP (Honma and Shimomura 1978), various pioneering research work conducted, such as in Jacobson et al. (1994), Glick (1995) and Penrose et al. (2001), have successfully elaborated the biochemical properties of this enzyme and its functional roles in controlling ethylene production in higher plants.

In general, the plant hormone ethylene plays important diverse roles in the growth of plants, such as root initiation and fruit ripening (Burg and Burg 1962; Arshad and Frankenberger 1991; Kende 1993). As a stress hormone, ethylene is involved in various stress responses induced by biotic (pathogenic attack) and abiotic (environmental) factors. Its biosynthesis starts with the $S$-adenosylation of methionine to $S$-adenosylmethionine (SAM) followed by the closing of a cyclopropane ring to form ACC. The ACC is then oxidatively cleaved to form ethylene. In spite of its beneficial roles in root induction, increased concentrations of plant ethylene at the vegetative stage inhibits root development, nodule formation and auxin transport and promotes senescence and abscission (Glick 1995; Shah et al. 1997; Wang et al. 1997; Ma et al. 2002; Glick et al. 2007). The antagonistic function of ethylene with IAA prevents the overgrowth (gigantism) of plants. IAA promotes rooting, but rooting is opposed by ethylene generated by IAA; thus, the promotion effects of IAA on root development can be outweighed by the inhibitory effect of ethylene (Burg 1968; Chadwick and Burg 1970; Arshad and Frankenberger 1991). The complex role of ethylene in plant-microbe interactions elicits ideas to regulate it for various purposes; it is required by both plants for resistance to pathogenic attack and by pathogens for disease susceptibility (Kunkel and Brooks 2002).

The importance of ACC deaminase-producing bacteria on plant growth is to control ethylene biosynthesis in plant tissues which is triggered by a number of biotic and abiotic factors. Inoculation of plant with ACC deaminase-producing bacteria can reduce the inhibition-effects of ethylene, and so ultimately increase plant growth. Evidence that ACC deaminase-producing bacteria increase the growth of various agricultural crops has been reported by various researchers, including those using transformed bacterial strains receiving the ACC deaminase gene ( $a c d S$ gene) as described by Wang 
et al. (2000). Interestingly, some root-nodule-forming bacteria may produce ACC-deaminase besides producing rhizobitoxine (an ethylene inhibitor) as a strategy by these bacteria to reduce the amount of ethylene synthesized in soybeans (Ma et al. 2002; 2003), otherwise the nodulation process would itself be inhibited. However, since ACC deaminase is a cytoplasmic enzyme in bacteria, the substrate of ACC must be exuded by plant tissues and taken up by the bacteria in the rhizosphere and subsequently hydrolyzed into ammonia and $\alpha$-ketobutyrate (Jacobson et al. 1994; Shah et al. 1997; Glick et al. 1998). Thus, the success of these bacteria to promote and increase plant growth will depend much on their ability to colonize the root and compete with other soil microflora.

\section{Amelioration of Plant Stress}

Plants grown in the tropical peat-soils may encounter various biotic and abiotic stresses as explained above. In general, biotic stresses could be due to pathogenic attack, either a biotroph which colonizes living plant tissues or necrotroph which rapidly kill plant cells to obtain nutrients. Meanwhile, abiotic or environmental stresses could be due to soil acidity, water-logging (osmotic pressure), nutrient shortage and phytotoxins that are generally present in tropical peat-soils. Both kinds of stressors may trigger plants to produce stress hormones as a signal to reduce the severity of the stress (Wang et al. 2000; Glick et al. 2007).

It has been known that several plant pathogenic microbes have developed the ability to modulate signaling processes mediated by plant hormones as a strategy for manipulating plant growth or host physiology (Lund et al. 1998). Three kinds of plant hormones, which are important in mediating plant defenses against pathogen attack, are salicylic acid (SA), jasmonic acid (JA) and ethylene (Kunkel and Brooks 2002; Glazebrook 2005). Ethylene signaling, however, plays a pivotal role in various types of stresses including those caused by various environmental factors (Glick et al. 2007).

Taken together, plants with a particular stress will accumulate high levels of ethylene that make them in a state of ethylene-stress and further inhibit their growth. Increasing levels of ethylene eventually exacerbates the stress which weakens plant protection against the stressors. In this condition, plants may not respond well to the availability of

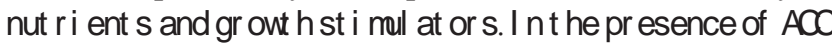

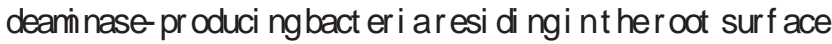

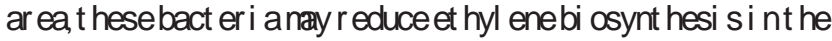

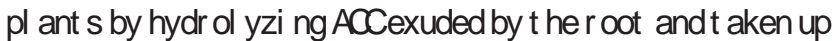

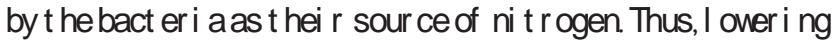

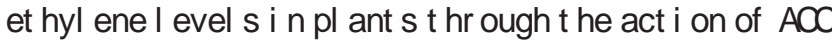

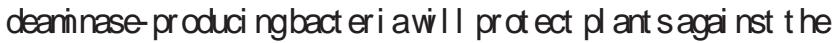

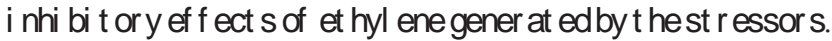



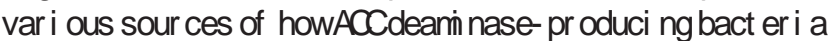

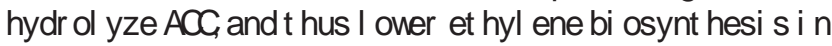

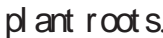

\section{Prospective Use of ACC Deaminase-Producing Bacteria}

The successful use of ACC deaminase-producing bacteria to assist plant growth under unfavorable soil conditions provides farmers an attractive method of

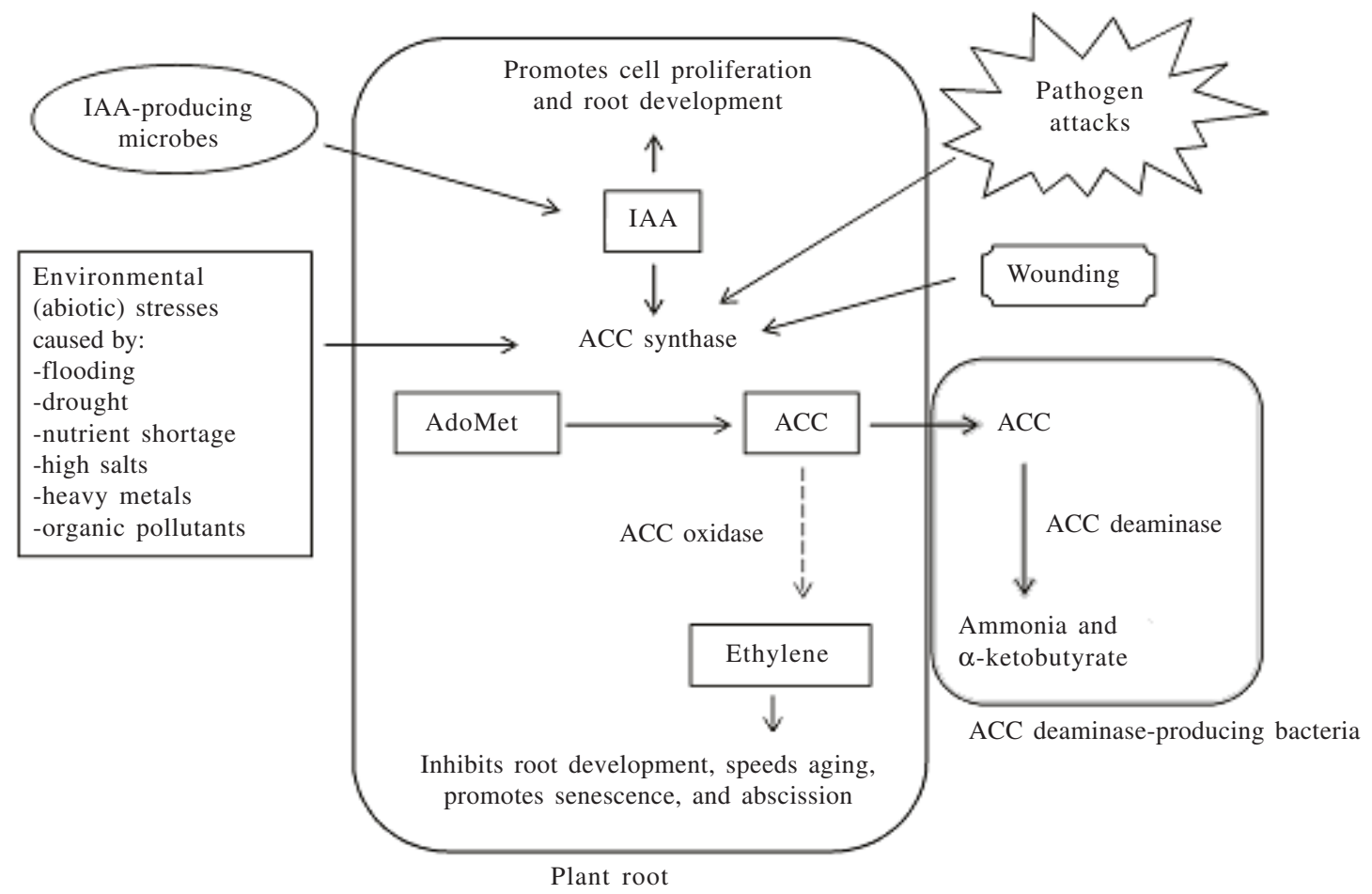

Fig 1 Schematic representation by which ACC deaminase-producing bacteria attached to plant roots lower ethylene biosynthesis. A key enzyme ACC synthase that converts AdoMet (S-adenosylmethionine) to ACC is induced by various biotic and abiotic factors including increased IAA concentrations. Bacterial uptake and hydrolysis of ACC exuded by plant roots (to maintain the equilibrium between internal and external ACC) prevents ethylene accumulation which inhibits plant growth. IAA, indoleacetic acid; ACC, 1-aminocyclopropane-1-carboxylic acid; AdoMet, S-adenosylmethionine. 
increasing crop production. Their ability to promote plant growth as well as to protect the plant against biotic and abiotic stresses may reduce the level of application of fertilizers and pesticides, which currently become more expensive and also alleviate environmental problems. The challenge that remains ahead is to obtain a good candidate of ACC deaminase-producing bacteria which can live and proliferate in peat-soils and which are effective to assist plant defense against a wide range of stressors. Since none of the studies on the use of ACC deaminase-producing bacteria has been specifically conducted yet in tropical peat-soil conditions which posses a complex of constraints, a complete screening of the bacteria is required to ensure that no deleterious traits are present in the bacteria that might negate their effectiveness in this role.

\section{ACKNOWLEDGEMENT}

Work on ACC deaminase-producing pseudomonads presented in this paper is part of the research funded by the "KKP3T" Project (Collaborative Research Project between Agency for Agricultural Research and Development, the Indonesian Ministry of Agriculture and Bogor Agricultural University, the Indonesian Ministry of Education) awarded to Aris Tri Wahyudi, Department of Biology, Faculty of Mathematics and Natural Sciences, Bogor Agricultural University (IPB), Bogor.

\section{REFERENCES}

Arshad M, Frankenberger WT Jr. 1991. Microbial production of plant hormones. Plant and Soil 133:1-8.

Belimov AA, Safranova FI, Sergeyeva TA, Egorova TN, Matveyeva VA, Tsyganov VE, Borisov AY, Tikhonovich IA, Kluge C, Preisfeld A, Dietz KJ, Stepanok VV. 2001. Characterization of plant growth promoting rhizobacteria isolated from polluted soils and containing 1-aminocyclopropane-1-carboxylate deaminase. Can J Microbiol 47:642-652.

Belimov AA, Safronova VI, Mimura T. 2002. Response of spring rape (Brassica napus var. oleifera L.) to inoculation with plant growth promoting rhizobacteria containing 1aminocyclopropane-1-carboxylate deaminase depends on nutrient status of the plant. Can J Microbiol 48:189-199.

Blum U, Shafer SR, Lehman ME. 1999. Evidence for inhibitory allelopathic interactions involving phenolic acids in field soils: Concepts vs. an experimental model. Crit Rev Plant Sci 18:673693.

Breemen N van. 1995. How sphagnum bogs down other plants. Trends Ecol Evol 10:270-275.

Burg SP, Burg EA. 1962. The role of ethylene in fruit ripening. Plant Physiol 37:179-189.

Burg SP. 1968. Ethylene formation in pea seedlings; its relation to inhibition of bud growth caused by indole-3-acetic acid. Plant Physiol 43:1069-1074.

Chadwick AV, Burg SP. 1970. Regulation of root growth by auxin: ethylene interaction. Plant Physiol 45:192-200.

Driessen PM, Subagjo. 1977. Growth and subsidence of Indonesian ombrogenous peats. A semi-quantitative approach. Proceedings $3^{\text {rd }}$ ASEAN Soil Conference on Soil Science for Agriculture Development. Kuala Lumpur, Malaysia, Nov 26 - Dec 5, 1975. p 409-417.

Feng L, Roughley RJ, Copeland L. 2002. Morphological changes of rhizobia in peat cultures. Appl Environ Microbiol 68:1064-1070.

Glazebrook J. 2005. Contrasting mechanisms of defense against biotrophic and necrotrophic pathogens. Annu Rev Phytopathol 43:205-227.
Glick BR. 1995. The enhancement of plant growth by free-living bacteria. Can J Microbiol 4:109-117.

Glick BR, Penrose DM, Li J. 1998. A model for the lowering of plant ethylene concentrations by plant growth promoting bacteria. $J$ Theor Biol 190:63-68.

Glick BR, Todorovic B, Czarny J, Cheng Z, Duan J. 2007. Promotion of plant growth by bacterial ACC deaminase. Crit Rev Plant Sci 26:227-242.

Grichko VP, Glick BR. 2001. Amelioration of flooding stress by ACC deaminase-containing plant growth promoting bacteria. Plant Physiol Biochem 39:11-17.

Hartatik W, Suriadikarta DA. 2003. Perbaikan sifat kimia tanah gambut yang disawahkan dengan pemberian bahan amelioran tanah mineral. In: Prosiding Seminar Nasional Sumberdaya Lahan. Cisarua-Bogor, Aug 6-7, 2002. p 165-188.

Honma M, Shimomura T. 1978. Metabolism of 1aminocyclopropane-1-carboxylic acid. Agric Biol Chem 42:18251831 .

Hoitink HAJ, Boehm MJ. 1999. Biocontrol within the context of soil microbial communities: a substrate-dependent phenomenon. Annu Rev Phytopathol 37:427-446.

Huang JW, Kuhlman EG. 1991. Formulation of a soil amendment to control damping-off of slash pine seedlings. Phytopathology 81:163-170.

Hunter PJ, Petch GM, Calvo-Bado LA, Pettitt TR, Parsons NR, Morgan JAW, Whipps JM. 2006. Differences in microbial activity and microbial populations of peat associated with suppression of damping-off disease caused by Pythium sylvaticum. Appl Environ Microbiol 72:6452-6460.

Husen E, Wahyudi AT, Suwanto A, Saraswati R. 2008. Soybean root growth promotion by 1-aminocyclopropane-1-carboxylate deaminase-producing pseudomonads. Indones J Agric Sci (In press).

Jacobson CB, Pasternak JJ, Glick BR. 1994. Partial purification and characterization of ACC deaminase from the plant growth promoting rhizobacterium Pseudomonas putida GR12-2. Can $J$ Microbiol 40:1019-1022.

Kende H. 1993. Ethylene biosynthesis. Апnи Rev Plant Physiol Plant Mol Biol 44:283-307.

Kunkel BN, Brooks DM. 2002. Cross talk between signaling pathways in pathogen defense. Curr Opin Plant Biol 5:325-331.

Lund ST, Stall RE, Klee HJ. 1998. Ethylene regulates the susceptible response to pathogen infection in tomato. Plant Cell 10:371382.

Ma W, Penrose DM, Glick BR. 2002. Strategies used by rhizobia to lower plant ethylene levels and increase nodulation. Can J Microbiol 48:947-954.

Ma W, Guinel FC, Glick BR. 2003. Rhizobium leguminosarum Biovar viciae 1-aminocyclopropane-1-carboxylate deaminase promotes nodulation of pea plants. Appl Environ Microbiol 69:4396-4402.

Malmer N, Svensson BM, Wallen B. 1994. Interactions between Sphagnum mosses and field layer vascular plants in the development of peat-forming systems. Folia Geobot Phytotax 29:483-496.

Mayak S, Tirosh T, Glick BR. 2004. Plant growth-promoting bacteria that confer resistance to water stress in tomato and pepper. Plant Sci 166:525-530.

McKenzie WE. 1974. Criteria used in soil taxonomy to classify organic soils. Soil Sci Soc Amer 6:1-10.

Penrose DM, Moffatt BA, Glick BR. 2001. Determination of 1aminocyclopropane-1-carboxylic acid (ACC) to assess the effects of ACC deaminase-containing bacteria on roots of canola seedlings. Can J Microbiol 47:77-80.

Ponnamperuma FN. 1972. The chemistry of submerged soils. $A d v$ Agr 24:29-96.

Reed MIE, Glick BR. 2005. Growth of canola (Brassica napus) in the presence of plant growth-promoting rhizobacteria and either copper or polycyclic aromatic hydrocarbons. Can J Microbiol 51:1061-1069.

Rubec C. 1996. Introduction to the workshop and overview of the global peat resource. In: Proceedings of an International Workshop (Global Mire and Peatland Conservation). North American Wetlands Conservation Council; Canada, Mar 18, 1996. p 1-5. 
Salampak S. Sabiham, Rieley JO 2000. Phenolic acids in tropical peat from Central Kalimantan. Int Peat J 10:97-103.

Saravanakumar D, Samiyappan R. 2007. ACC deaminase from Pseudomonas fluorescens mediated saline resistance in groundnut (Arachis hypogea) plants. J Appl Microbiol 102:1283-1292.

Shah S, Li J, Moffatt BA, Glick BR. 1997. ACC deaminase genes from plant growth promoting rhizobacteria. In: Proceedings of the Fourth International Workshop on PGPR. Japan-OECD Joint Workshop. Sapporo, Japan, Oct 5-10, 1997. p 320-324.
Wang C, Knill E, Glick BR, Defago G. 2000. Effect of transferring 1aminocyclopropane-1-carboxylic acid (ACC) deaminase gene into Pseudomonas fluorescens Strain $\mathrm{CHA} 0$ and its gacA derivative CHA96 on their growth-promoting and disease-suppressive capacities. Can J Microbiol 46:898-907.

Widjaya-Adhi IPG. 1997. Developing tropical peatlands for agriculture. In: Proceedings of International Symposium on Biodiversity, Environmental Importance and Sustainability of Tropical Peat and Peatlends. Palangka Raya, Indonesia, Sep 4-8, 1995. p 293-300. 